AGRICULTURE AND BIOLOGY JOURNAL OF NORTH AMERICA

ISSN Print: 2151-7517, ISSN Online: 2151-7525, doi:10.5251/abjna.2010.1.5.1061.1068

(C) 2010, ScienceHuß, http://www.scihub.org/ABJNA

\title{
Increasing imazapyr-resistant maize yield by increasing plant density under natural Striga hermonthica infestation
}

\author{
IIla A.O ${ }^{1}$, Odhiambo G.D ${ }^{1}$ and Dida M.M ${ }^{1}$ \\ ${ }^{1}$ Maseno University, Department of Botany and Horticulture, P.O. Box 333, Maseno, Kenya.
}

\begin{abstract}
Maize (Zea mays L.) is one of the most important crops in East Africa serving both as a staple food and cash crop to millions of people. As a vegetable, it is produced as green maize cobs, sweet corn or baby corn. Yields under farmers' conditions in the Lake Victoria Basin average $1.3 \mathrm{t}$ $\mathrm{ha}^{-1}$ which is less than $25 \%$ of the potential yield. This is attributed to several factors; the greatest being Striga (Striga hermonthica) which is a parasitic weed attacking several crops in the grass family. A medium term technological breakthrough in form of a herbicide (imazapyr) resistant maize variety has been developed to help reduce Striga infestation. The optimum maize plant population for effective seedbank reduction and optimum grain yield has however not been determined. The main objective of this study was therefore to evaluate the performance of imazapyr-resistant (IR) maize at different plant densities on Striga weed incidence and crop growth. The study was conducted for two seasons on a naturally infested Striga field in Western Kenya. The experiment was laid out as a split plot with three replications. Maize variety (treated IR maize, untreated IR maize and WH505/H516 commercial checks) was the main plot factor and density $\left(44,444,66,666\right.$ and 88,888 plants ha $\left.^{-1}\right)$ as the sub-plot factor. Data was collected on maize stand, days to first Striga emergence, Striga incidence, Striga biomass, maize biomass and its yield components. Treated IR maize delayed Striga emergence on maize thus suppressing Striga parasitism. Any late Striga attachments had little or no effect on maize growth. Increasing the plant density of treated IR maize from 44,444 to 88,888 plants ha ${ }^{-1}$ did not affect Striga incidence but increased maize yield from 1.60 to $3.48 \mathrm{t} \mathrm{ha}^{-1}$. It is therefore recommended that treated IR maize should be planted in Striga infested fields at $75 \mathrm{~cm} \times 15 \mathrm{~cm}$ to hasten Striga seed bank reduction and maximize on maize yield to improve staple food availability.
\end{abstract}

Keywords: herbicide treated maize; parasitic weed; maize yield

\section{INTRODUCTION}

Maize (Zea mays L.) is one of the most important cereal crops in the Lake Victoria Basin of East Africa where it is both a staple food and cash crop. Maize yields under farmers' conditions in the region average $1.3 \mathrm{t} \mathrm{ha}^{-1}$ (Hassan, 1998), or less than $25 \%$ of the potential yield of $5 \mathrm{t} \mathrm{ha}^{-1}$ (Tittonell et al., 2005) under rainfed conditions. Reduced maize yields in the region are mainly attributed to the parasitic weed, Striga hermonthica (Del.) Benth amongst other constraints like declining soil fertility, pests and diseases (Odendo et al., 2001). This yield reduction has greatly contributed to food insecurity since maize is the main staple food within the region; this has been made worse by the climatic change which has engulfed the whole world.

Striga (Striga hermonthica (Del.) Benth) is a parasitic weed that attacks cereal crops; maize, sorghum, rice, finger millet and other native and exotic grasses throughout Africa, and elsewhere in the tropics (Odhiambo and Woomer, 2005). In Kenya, Striga infestation is most severe in Nyanza and Western Provinces, where it infests approximately 200,000 ha of land and resulting in crop losses estimated at $30-$ $50 \%$ although losses of up to $100 \%$ are reported (Hassan et al., 1995) with a value of $\$ 80$ million per year.

Continued attempts to combat Striga by uprooting during weeding and burning has not reduced the parasite's infestation owing to the enormous seed bank in the soil (AATF, 2006). A recent technological breakthrough using the herbicide resistant maize variety has been developed (Kanampiu et al., 2002). An application of relatively small amounts of a systemic herbicide imazapyr to maize seeds provides up to 8 weeks chemical protection from Striga weed (Kanampiu et al., 2002). The approach has been developed on the understanding that parasitic witchweeds inflict most of their damage while still underground and attached to the crop roots (Ramaiah et al., 1983). The herbicide is absorbed and translocated in the xylem and phloem tissues of 
the roots where it inhibits the enzyme acetolactate synthase in the attached Striga seedling (Tu, 2004). The imazapyr not absorbed by the maize seedling diffuses into the surrounding soil and kills ungerminated Striga seeds. The coated maize also exudes germination stimulants into the rhizosphere thereby inducing germination of Striga seeds which are then killed (Kanampiu et al., 2001). The low dose herbicide seed dressing on IR-maize controls Striga without impacting sensitive intercrops planted $10 \mathrm{~cm}$ or more from the maize hills (CIMMYT, 2008). It therefore allows small scale farmers to continue intercropping with other legumes with slight modification.

The effect of IR maize on Striga incidence and crop growth and yield has been determined at a single density of 44,000 plants $\mathrm{m}^{-2}$. Increasing IR maize plant density leads to increased root surface area thus greater impact of IR maize on Striga weed. There is therefore a need to determine its effect on Striga at higher plant densities. This study was therefore conducted to evaluate the effect of imazapyr-resistant maize at different plant densities on Striga weed and maize productivity.

\section{MATERIALS AND METHODS}

Field trials were conducted for two consecutive seasons (long and short rains of 2008) in a farmer's field naturally infested with Striga in Maseno situated in western Kenya $\left(00^{\circ} 01.979^{\prime} \mathrm{S}\right.$ and $\left.34^{\circ} 36.459^{\prime} \mathrm{E}\right)$ at an altitude of $1449 \mathrm{~m}$. This is within the Upper Midland 1 agro ecological zone.

The experiment was laid out as a split plot with maize variety (treated IR maize, untreated IR maize and $\mathrm{WH} 505 / \mathrm{H} 516)$ as the main plots and plant density $\left(44,444,66,666\right.$ and 88,888 plants ha $\left.^{-1}\right)$ as the subplots with three replications. Plots were hand ploughed and harrowed to a fine tilth. Twenty seven (27) plots each measuring $5 \mathrm{~m} \times 3 \mathrm{~m}$ were marked out in three blocks of nine plots each with $1 \mathrm{~m}$ paths between the blocks and $0.5 \mathrm{~m}$ between the plots. Soil samples were collected from every plot to characterize the initial Striga seed bank. Treated and untreated IR maize seeds were obtained from the International maize and wheat improvement centre (CIMMYT) while the commercial checks were purchased from input shops. $150 \mathrm{~g}$ of pre-plant fertilizer, diammonium phosphate (DAP) was uniformly applied along the furrows in each experimental unit and incorporated into the soil to provide $46 \mathrm{~kg} \mathrm{P}_{2} \mathrm{O}_{5} \mathrm{ha}^{-1}$ and $18 \mathrm{~kg} \mathrm{~N} \mathrm{ha}^{-1}$. The maize seeds were sown to the required density in each plot using a rope to give five rows each $5 \mathrm{~m}$ long. Weeding was done using a hand hoe at 2 and 4 weeks after crop emergence (WAE) but before Striga emergence. This was followed by hand pulling of other weeds as necessary to facilitate observation of emerged Striga plants. After the second weeding, $300 \mathrm{~g}$ of calcium ammonium nitrate (CAN) was applied per plot as a top-dress to top up to the required $60 \mathrm{~kg} \mathrm{~N} \mathrm{ha}^{-1}$.

Data was collected from the net plot area of $7.5 \mathrm{~m}^{2}$ which consisted of three middle maize rows. The parameters observed included stand count taken 14 days after crop emergence by counting the number of plants per net plot area. Days to first Striga emergence was recorded as the number of days from crop emergence to the date of first Striga emergence in any of the 27 plots by observing a small whitish protrusion above the ground. Striga incidence and biomass at 8 and 10 weeks after crop emergence (WAE) was determined by counting the number of emerged Striga plants per sample area. All the emerged Striga plants within the sample area were uprooted during each counting stage, placed in a paper bag and weighed using an electronic weighing balance to get the fresh weight. They were then dried in an oven at $72^{\circ} \mathrm{C}$ until a constant weight was obtained then the dry weight was recorded for Striga biomass determination. Days to crop flowering was determined as the number of days from the date of crop emergence to the date when $50 \%$ of the plant population had reached tasseling. Crop biomass at $50 \%$ tassel emergence and at physiological maturity was determined by the weight of the above ground vegetative growth. Three plants were harvested destructively at the respective stages, chopped and placed in paper bags then weighed using a weighing balance to obtain the fresh weight. They were then dried in an oven at $72^{\circ} \mathrm{C}$ to a constant weight to obtain the dry weight which was then used to convert biomass to $\mathrm{t} \mathrm{ha}^{-1}$. Crop yield and yield components included the number of ears of maize, kernels/ear, dry weight of maize, and 100 seed weight.

Data was subjected to analysis of variance (ANOVA) at $5 \%$ level of significance using the General Linear Model of SAS statistical package to test for significant differences (SAS, 2003). Striga incidence and biomass data with large variations were transformed using the formula $\sqrt{ }(\mathbf{X + 0 . 5 )}$ where $\mathbf{X}$ is the number of Striga plants $\mathrm{m}^{-2}$ or biomass in $\mathrm{t} \mathrm{ha}^{-1}$. (Little and Hills, 1978). Significant means were separated using the Least Significant Difference (LSD) at 5\% probability level. Linear regression was used to compare the 
relationship between Striga incidence and maize yield.

\section{RESULTS AND DISCUSSION}

Days to first Striga emergence: The farmer' field was under natural Striga infestation. Analysis of data collected in two seasons showed no significant interaction between maize variety and planting density on the days to first Striga emergence in both seasons. However, there were highly significant differences $(p<0.0001)$ between maize varieties. In the long rains, treated IR-maize took significantly longer (54 days) for the first Striga to emerge compared to both untreated IR-maize and the commercial check that took 36 days (Table 1). In the short rains, it took slightly more days for first Striga to emerge with treated IR maize taking 58 days which significantly differed from 38 days for the untreated IR and 36 days for the local check variety. Days to first Striga emergence are an indication of early season conditioning and ability to attach to the host crop. There was therefore suppression of Striga attachment from the treated IR maize as the herbicide coating on the seeds killed most of the early attached Striga seedlings when the herbicide was still active in the maize plant resulting in late emergence in the treated IR maize as previously observed by Abayo et al., (1998). Commercial varieties WH505 and H516 or the untreated IR-maize did not have any protection, thus the Striga was able to attach early. Early Striga attachment affects the host crop growth resulting in significant crop yield loss (De Groote et al., 2007, Vanlauwe et al., 2008). Late emergence was an indication of late attachment, the crop was thus protected from Striga parasitism during the critical initial growth period (8 weeks) of the crop. The late attachments could be attributed to a decrease in herbicide activity with time due to dilution by infiltrating rainfall and herbicide breakdown (Pusino et al., 1997) and given that a very low dosage $\left(30 \mathrm{~g} \mathrm{ha}^{-1}\right)$ of the herbicide was used compared to the $600 \mathrm{~g} \mathrm{ha}^{-1}$ used for the commercial product. Maize plant density did not affect days to first Striga emergence (Table 1) indicating that plant density is not a factor affecting the time when Striga is attached but only affects the number that is attached to the maize plant.

Table 1: Mean number of DTSE and Striga counts for maize varieties and planting densities in a farmers' field during 2008

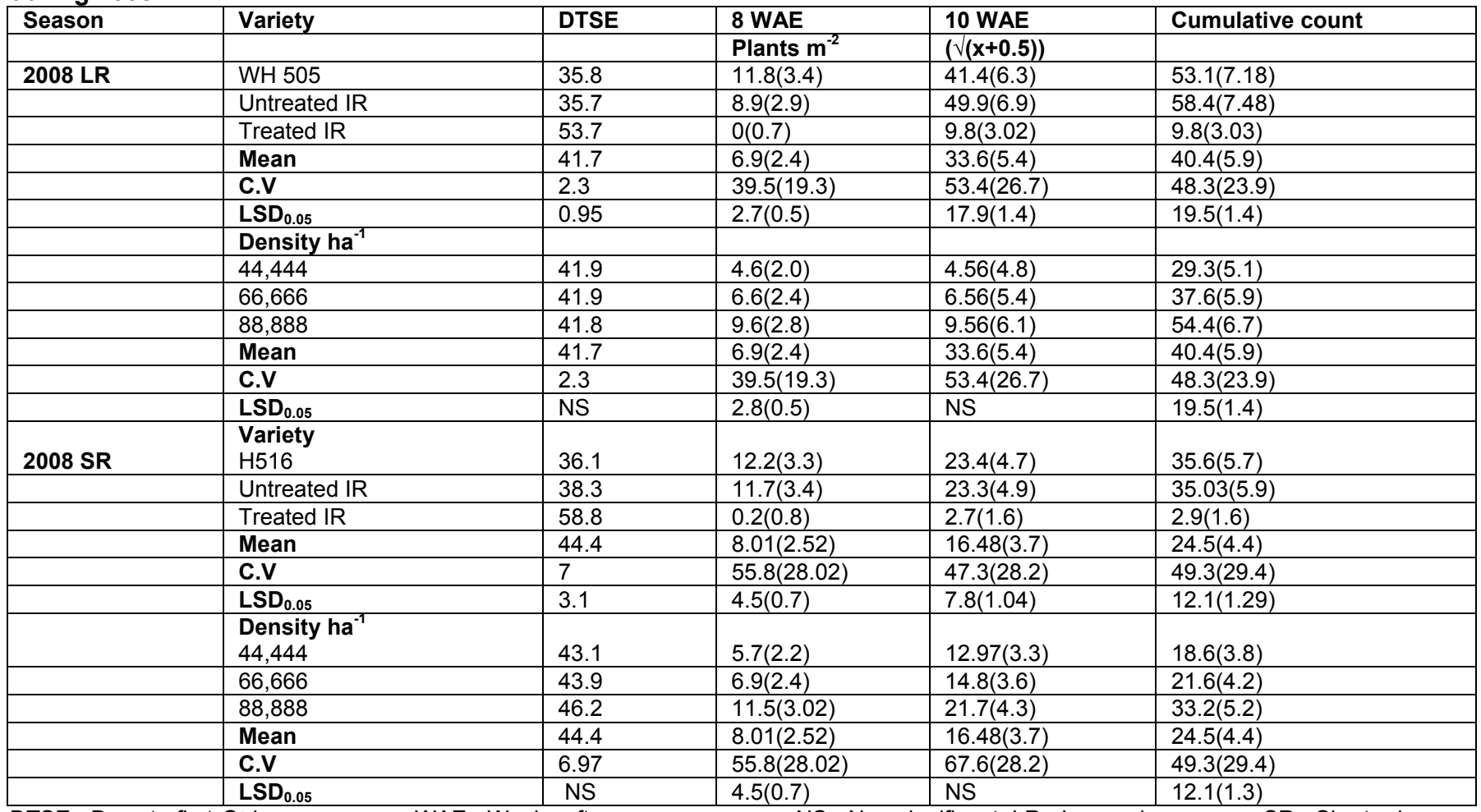

DTSE= Days to first Striga emergence, WAE= Weeks after crop emergence, NS= Non significant, LR= Long rains season, SR= Short rains season.

Values in brackets are from transformations 
Striga emergence: The Striga emergence was higher in the long rains season compared to the short rains season (Table 1). The low Striga counts in the short rains could be attributed to the drought situation which prevailed during the short rains as earlier observed by Odhiambo and Woomer, (2005). Extended optimum water availability during Striga seed conditioning is necessary to enhance maximum germination. Water stress during conditioning therefore strongly suppresses germination of the seeds (Dzomeku and Murdoch, 2007).

During both the long and short rains seasons, the Striga counts showed highly significant differences between maize varieties and planting densities at both 8 and 10 weeks after crop emergence (WAE) (Table 1). In both the long and short rains at 8 WAE commercial check and untreated IR maize had significantly higher emerged Striga plants $\mathrm{m}^{-2}$ compared to treated IR maize which had no Striga. By $10 \mathrm{WAE}$, the commercial check and the untreated IR maize Striga counts had significantly increased to 41 and 50 plants $\mathrm{m}^{2}$ respectively compared to treated IR maize with 10 Striga plants $\mathrm{m}^{-2}$ (Table 1). Cumulative Striga emergence in treated IR maize was 9.8 and 2.9 plants $\mathrm{m}^{2}$ which were significantly lower compared to between 35 and 55 plants $\mathrm{m}^{2}$ in the untreated IR and check varieties for 2008 long and short rains, respectively. The low herbicide dosage of $30 \mathrm{~g} \mathrm{ha}^{-1}$ was capable of protecting the IR maize during the critical stage of Striga parasitism and Striga was able to emerge from treated IR-maize later in the season with minimal parasitic effect (Kanampiu et al., 2002).

Maize plant density only significantly affected Striga emergence at 8 WAE during long and short rains, although in both seasons higher maize density resulted in more emergence whether the maize was protected or not (Table 1). The highest planting density of 88,888 plants ha $^{-1}$ had significantly higher Striga emergence than 44,444 plants ha ${ }^{-1}$ at $8 \mathrm{WAE}$ in both seasons across all maize varieties. The higher plant density of 88,888 plants ha ${ }^{-1}$ also had significantly higher mean cumulative Striga emergence of 54 and 33 plants $\mathrm{m}^{-2}$ than 44,444 plants ha $^{-1}$ during both the long and short rains season respectively (Table 1 ). This could be attributed to the higher root surface area at the high maize density resulting in high amounts of Striga germination stimulant exuded from the host roots (Babalola and Odhiambo, 2007). The high germination stimulant and the presence of a suitable host increased the chances of Striga germination and attachment (Berner et al., 1995). This explains the higher Striga emergence in high maize plant density which can then be hand pulled to reduce seed bank in the soil as a long term strategy to eliminate the threat posed by the weed.

Striga biomass: Striga were counted and uprooted as they emerged to determine their biomass. During the long rains season there were highly significant differences between maize varieties at 8 and 10 WAE, respectively. The local check had the highest Striga biomass of $0.02 \mathrm{t} \mathrm{ha}^{-2}$ followed by untreated IR maize with $0.01 \mathrm{t} \mathrm{ha}^{-2}$ while treated IR-maize had no Striga at 8 WAE (Table 2). Treated IR maize also had the lowest Striga biomass at 10 WAE. Planting densities only significantly affected Striga biomass at $8 \mathrm{WAE}$. The highest planting density had the highest Striga biomass of $0.01 \mathrm{t} \mathrm{ha}^{-2}$ at 8 WAE. In the short rains season, a similar trend was observed with the local check having the highest Striga biomass of 0.01 and $0.04 \mathrm{t} \mathrm{ha}^{-2}$ at 8 and 10 WAE respectively (Table 2). The check varieties WH505 and H516 and the untreated IR-maize were susceptible to Striga parasitism thus after attachment, the Striga became a metabolic sink for the carbohydrates produced in the host (Ramaiah et al., 1983) and consequently led to high Striga biomass accumulation. The high crop density with a high host root surface area led to high amount of Striga seed germination thus higher Striga emergence and subsequently higher biomass.

Maize biomass: During the long and short rains seasons, maize biomass was determined at flowering and at maturity. There were highly significant differences between the maize varieties on maize biomass both at flowering and at crop maturity during long rains season only (Table 3 ). At flowering, treated IR maize had significantly higher biomass of $0.45 \mathrm{t}$ $\mathrm{ha}^{-1}$ which was three times the commercial check variety and untreated IR maize which were not significantly different from each other. At maturity, all the three varieties differed significantly with treated IR maize having the highest biomass of $0.61 \mathrm{t} \mathrm{ha}^{-1}$; $\mathrm{WH}$ 505 accumulated more biomass between flowering and crop maturity compared to untreated IR maize (Table 3 ). The biomass accumulated by the treated IR maize at flowering alone was higher than the individual accumulated biomass of the other two varieties at maturity. Biomass accumulation was affected by variety whereby the treated IR-maize accumulated more biomass than the untreated IRmaize and the WH505. The low biomass accumulation in the untreated IR-maize and WH505 was attributed to the effect of Striga parasitism on 
these two susceptible varieties which had high Striga emergence compared to the treated IR-maize. Due to the high number of emerged Striga plants in the two unprotected varieties, there was high level of parasitism leading to diversion of nutrients to the parasite thus less biomass accumulation. The parasitic Striga predisposes the host to photoinhibition or photo-damage during periods of high irradiances thereby lowering the ability of the host to fix carbon especially due to Striga-induced stomatal closure (Gurney et al., 2000). Whereas the differences in biomass accumulation in the long rains season were majorly attributed to Striga parasitism, this might not have had significant effects in the short rains season owing to the low Striga counts observed and the general low moisture levels due to drought

Table 2: Mean Striga biomass for maize varieties and planting densities in a farmers' field during 2008.

\begin{tabular}{|c|c|c|c|c|}
\hline Season & Variety & 8 WAE $\left(\mathrm{t} \mathrm{ha}^{-1}\right)$ & 10 WAE $\left(t^{h a^{-1}}\right)$ & Cumulative biomass $\left(\mathrm{t} \mathrm{ha}^{-1}\right)$ \\
\hline \multirow[t]{13}{*}{2008 LR } & WH 505 & $0.017(0.719)$ & $0.045(0.737)$ & $0.062(0.750)$ \\
\hline & Untreated IR & $0.011(0.715)$ & $0.041(0.736)$ & 0.052(0.743) \\
\hline & Treated IR & $0.000(0.707)$ & $0.007(0.712)$ & $0.007(0.712)$ \\
\hline & Mean & $0.0094(0.713)$ & $0.031(0.728)$ & $0.04(0.73)$ \\
\hline & C.V & $45.1(0.42)$ & $73.2(2.1)$ & $63.2(2.3)$ \\
\hline & LSD $_{0.05}$ & $0.005(0.003)$ & $0.023(0.015)$ & $0.03(0.02)$ \\
\hline & Density ha $^{-1}$ & & & \\
\hline & 44,444 & $0.007(0.712)$ & $0.027(0.726)$ & $0.036(0.730)$ \\
\hline & 66,666 & $0.009(0.713)$ & $0.030(0.728)$ & $0.038(0.733)$ \\
\hline & 88,888 & $0.013(0.716)$ & $0.036(0.732)$ & \begin{tabular}{|l|}
$0.049(0.741)$ \\
\end{tabular} \\
\hline & Mean & $0.0094(0.713)$ & $0.031(0.728)$ & $0.04(0.73)$ \\
\hline & C.V & $45.1(0.42)$ & $73.2(2.1)$ & $63.2(2.3)$ \\
\hline & LSD $_{0.05}$ & 0.003 & NS & NS \\
\hline \multirow[t]{12}{*}{2008 SR } & $\begin{array}{l}\text { Variety } \\
\text { H516 }\end{array}$ & $0.014(0.717)$ & $0.038(0.733)$ & $0.051(0.742)$ \\
\hline & Untreated IR & $0.009(0.713)$ & $0.032(0.730)$ & $0.041(0.735)$ \\
\hline & Treated IR & $0.00006(0.707)$ & $0.0019(0.708)$ & $0.0019(0.708)$ \\
\hline & Mean & $0.0074(0.712)$ & $0.024(0.724)$ & $0.031(0.729)$ \\
\hline & C.V & $67.64(0.49)$ & $76.2(1.71)$ & $72.2(2.1)$ \\
\hline & $\mathrm{LSD}_{0.05}$ & $0.005(0.004)$ & $0.018(0.012)$ & $0.023(0.015)$ \\
\hline & $\begin{array}{l}\text { Density ha }{ }^{-1} \\
44,444\end{array}$ & $0.0047(0.710)$ & $0.018(0.720)$ & $0.023(0.73)$ \\
\hline & 66,666 & $0.0061(0.711)$ & $0.022(0.722)$ & $0.028(0.73)$ \\
\hline & 88,888 & $0.011(0.715)$ & $0.032(0.729)$ & $0.043(0.74)$ \\
\hline & Mean & $0.0074(0.712)$ & $0.0024(0.724)$ & $0.031(0.729)$ \\
\hline & C.V & $67.6(0.49)$ & $76.2(1.71)$ & $72.2(2.1)$ \\
\hline & $\mathrm{LSD}_{0.05}$ & 0.0035 & NS & NS \\
\hline
\end{tabular}

WAE = Weeks after crop emergence, $N S=$ Non significant, LR= Long rains season, SR= Short rains season.

Values in brackets are from transformation 
Agric. Biol. J. N. Am., 2010, 1(5): 1061-1068

Table 3: Mean maize performance under naturally infested farmers field during 2008

\begin{tabular}{|c|c|c|c|c|c|}
\hline \multirow[t]{2}{*}{ Season } & \multirow[t]{2}{*}{ Variety } & \multicolumn{2}{|c|}{ Maize biomass $\mathrm{t} \mathrm{ha}^{-1}(\sqrt{ }(X+0.5))$} & \multirow[t]{2}{*}{$100 \mathrm{MZ}$ seed wt $(\mathrm{g})$} & \multirow[t]{2}{*}{ Kernels $\mathrm{cob}^{-1}$} \\
\hline & & Flowering & Maturity & & \\
\hline \multirow[t]{6}{*}{2008 LR } & Treated IR & $0.45(0.97)$ & $0.61(1.05)$ & 22.9 & 502.7 \\
\hline & WH 505 & $0.18(0.82)$ & $0.31(0.89)$ & 17.9 & 205.9 \\
\hline & Untreated IR & $0.12(0.79)$ & $0.15(0.80)$ & 16.9 & 223.3 \\
\hline & Mean & $0.25(0.86)$ & $0.36(0.92)$ & 19.3 & 310.6 \\
\hline & C.V & $35.8(5.9)$ & $41.3(7.98)$ & 10.2 & 32.9 \\
\hline & $\mathrm{LSD}_{0.05}$ & $0.09(0.05)$ & $0.15(0.07)$ & 1.97 & 102.5 \\
\hline \multirow[t]{6}{*}{2008 SR } & Treated IR & $0.33(0.91)$ & $0.29(0.89)$ & 16.3 & 305.4 \\
\hline & H516 & $0.33(0.91)$ & $0.31(0.89)$ & 20.2 & 258.7 \\
\hline & Untreated IR & $0.29(0.89)$ & $0.27(0.88)$ & 17.6 & 249.6 \\
\hline & Mean & $0.32(0.9)$ & $0.29(0.89)$ & 18.0 & 271.2 \\
\hline & C.V & $40.8(7.9)$ & $38.6(7.2)$ & 19.3 & 17.4 \\
\hline & $\mathrm{LSD}_{0.05}$ & NS & NS & NS & 47.2 \\
\hline
\end{tabular}

$\mathrm{LR}=$ Long rains season, $\mathrm{SR}=$ Short rains season, $\mathrm{MZ}$ seed $\mathrm{wt}=$ Maize seed weight.

Values in brackets are from transformation

Maize grain yield and yield components: The number of maize cobs harvested showed significant interaction between maize variety and maize planting density during long rains season (Fig. 1). Increasing plant density led to a steady and significant increase in the number of cobs of treated IR maize from $28,000 \mathrm{ha}^{-1}$ at 44,000 plants ha ${ }^{-1}$ to $60,000 \mathrm{ha}^{-1}$ at 88,888 plants $\mathrm{ha}^{-1}$ while the number of cobs decreased in WH 505 from $28,000 \mathrm{ha}^{-1}$ to 19,000 $\mathrm{ha}^{-1}$ over the same range of plant density. The decrease in the number of cobs in this variety was due to Striga parasitism that led to barrenness of most plants. There were however no significant interactions in the short rains season but the commercial check variety had significantly higher number of cobs and grain yield. The higher number of cobs in treated IR maize resulted in more maize grain yield. During the long rains season, there was a significant interaction between maize varieties and plant density on maize yield. Increasing plant density in treated IR maize significantly increased maize grain yield while the yield of WH 505 decreased with increasing plant density (Fig.2). Treated IR maize at the highest plant density had a mean yield of $3.48 \mathrm{t}$ $\mathrm{ha}^{-1}$ at 88,000 plants ha ${ }^{-1}$ up from $1.5 \mathrm{t} \mathrm{ha}^{-1}$ at 44,444 plants ha-1 while WH505 decreased from $1.0 \mathrm{t} \mathrm{ha}^{-1}$ to $0.2 \mathrm{t} \mathrm{ha}^{-1}$ over the same density interval. Maize grain yield of untreated IR-maize was however not affected by the change in its density. Increasing plant density led to a yield increase in treated IR-maize and a decrease in WH505. The major factor affecting maize yield here was Striga infestation, thus with the suppression of Striga from the herbicide coating in the treated IR-maize, there was bound to be an increase in yield. The highest mean yield was therefore obtained from treated IR-maize at 88,888 plants ha $^{-1}$ indicating that with treated IR-maize under Striga infested fields, 88,888 plants $\mathrm{ha}^{-1}$ is still optimal. Increasing plant density in untreated IRmaize and WH505 led to more parasitic effects from increased Striga incidences resulting from high root surface area thus more Striga germination. This subsequently led to a substantial yield reduction. This could be supported by the report of Babalola and Odhiambo, (2007) that indicated that increasing plant density increases the proportion of plants without ears due to plant competition for nutrients and available resources.

The highest mean yield of $2.6 \mathrm{t} \mathrm{ha}^{-1}$ in treated IRmaize represented an increase of $2.3 \mathrm{t} \mathrm{ha}^{-1}(766 \%)$ above the untreated IR-maize and $2.0 \mathrm{t} \mathrm{ha}^{-1}$ (333\%) above the WH505. Early Striga attachments had severe effects on maize grain yield (Gurney et al., 2000). If Striga attachment is delayed then the effect on grain yield would significantly be reduced. The Striga also influences the physiology of the host resulting in lower grain and biomass accumulation, alters resource allocation and an impairment of host photosynthesis. Although the treated IR-maize had a few emerged Striga plants ha ${ }^{-1}$ at 10 weeks after crop emergence, these late attachments had little effect on maize grain yield. Kanampiu et al., (2001), had also indicated that the treated IR maize had only a few late attachments which had little effect on the crop. 


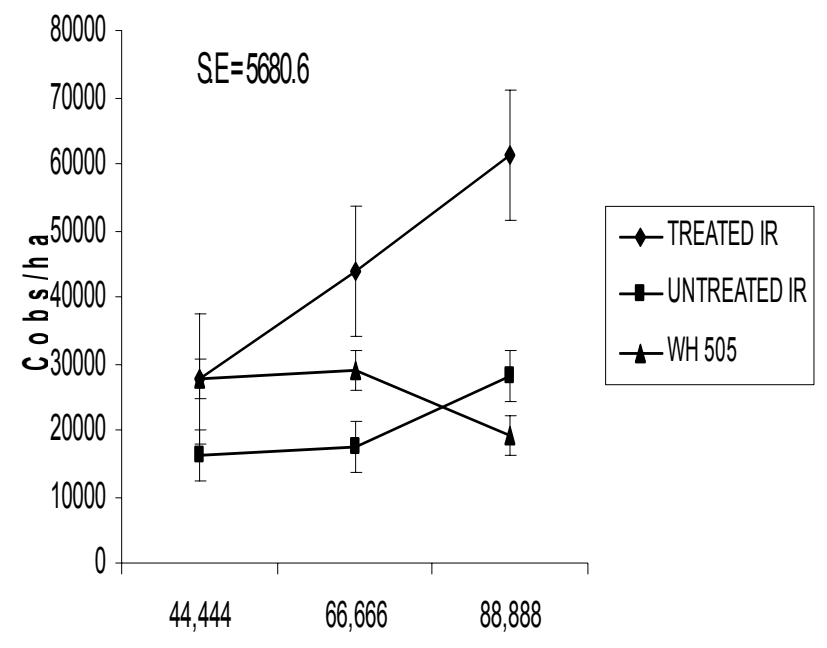

Density (Plants/ha)

Fig. 1: Mean number of cobs of maize varieties at various plant densities

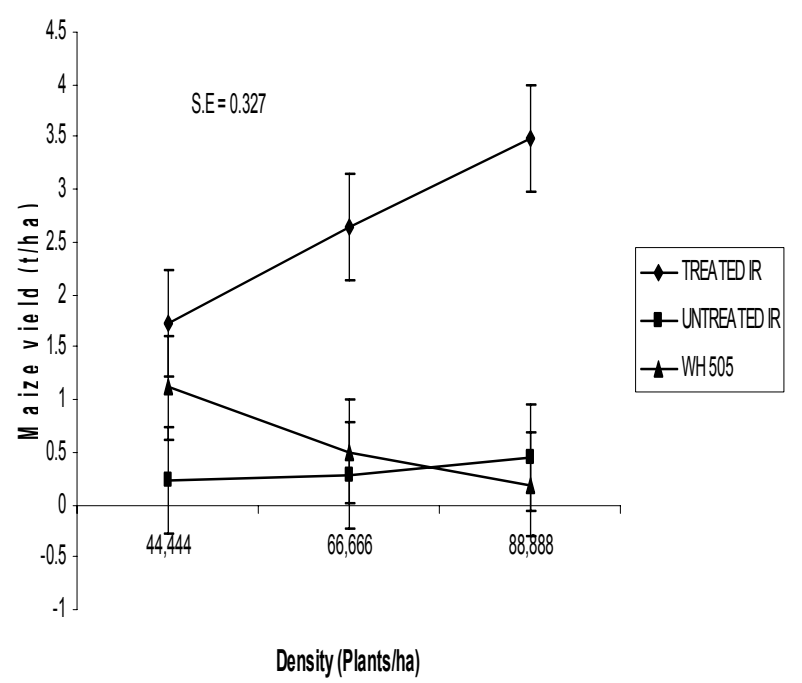

Fig. 2: Mean yield of maize varieties at various plant densities

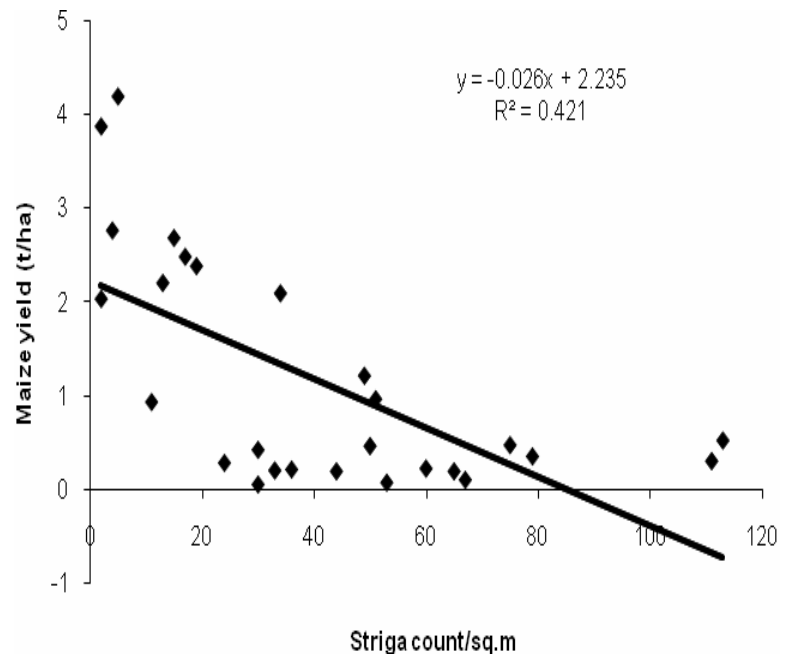

Fig 3: Relationship between total Striga emergence and maize grain yield

\section{CONCLUSIONS:}

This research conducted in a farmers' field under natural Striga infestation showed that coated IR maize was able to protect the crop with minimal Striga parasitism. The Striga emergence was low during the critical vegetative growth period with few if any late Striga attachments with little or no parasitic effects. Although higher maize plant density resulted in more Striga emergence, these can be hand pulled to prevent reseeding thus reduce seed bank in the soil in the long term. The treated IR maize yields higher with increased plant density of 88,888 plants ha $^{-1}$ as opposed to the Striga susceptible varieties which decreased grain yield. The positive attributes of IR maize are made possible by adequate rainfall without which the treated IR maize is not capable of attaining its full potential.

\section{ACKNOWLEDGEMENTS:}

The African Agricultural Technology Foundation (AATF) is highly acknowledged for funding the study through the Striga Technology Extension Project (STEP) implemented by the western research alliance for technology extension (WeRATE) consortium. Maseno University is also acknowledged for its support. 


\section{REFERENCES}

AATF, (2006). Empowering African Farmers to eradicate Striga from maize croplands. The African Agricultural Technology Foundation. Nairobi, Kenya.

Abayo, G.O., English, T., Eplee, R.E., Kanampiu, F.K., Ransom, J.K., and Gressel, J., (1998). Control of Parasitic witchweeds ( Striga Spp.) On corn (Zea mays) resistant to acetolactate synthase inhibitors. Weed Science 46: 459 - 466

Babalola, O.O., and Odhiambo, G.D., (2007). Klebsiella oxytoca ' $10 \mathrm{mkr7}$ ' stimulates Striga suicidal germination in Zea mays. Journal of Tropical Microbiology and Biotechnology 2: 13-19.

Berner, D.K., Kling, J.G., and Singh, B.B., (1995). Striga Research and Control; a perspective from Africa. Plant Disease 79(7): 652 - 659 .

CIMMYT, (2008). Striga Weed control with herbicidecoated maize seed from $<$ http://www.Cimmyt.org/Research/maize/results/contr ol.pdf $>$ accessed on 28/02/2008

De Groote, H. Wangare, L. and Kanampiu, F., (2007) Evaluating the use of herbicide-coated imidazolinoneresistant (IR) maize seeds to control Striga in farmers' fields in Kenya. Crop Protection 26, 1496-1506.

Dzomeku, I.K., and Murdoch, A.J., (2007). Effects of prolonged conditioning on Dormancy and Germination of Striga hermonthica. Journal of Agronomy 6(1): 2936.

Gurney, A.L., Adcock, M., Scholes, J.D., and Press, M.C., (2000). Physiological processes during Striga Infestation in maize and sorghum. In: Haussmann, B.I.G., Hess D.E., Koyama M.L., Grivet L., Rattunde H.F.W and Geiger H.H. (Eds), 2000. Breeding for Striga resistance in cereals. Proceedings of a workshop held at IITA, Ibadan Nigeria, from 18-20 August 1999. Margraf Verlag, Weikersheim, Germany. Pp 3-17.

Hassan, R., Ransom, J.K. and Ojiem, J.O., (1995). The spatial distribution and farmers strategies to control Striga in corn: survey results from Kenya. In: Jewell, D.C., Waddington, S., Ransom, J.K., Pixley, K., (Eds.), Proceedings of the fourth Eastern and Southern Africa Regional corn conference. CIMMYT, Harare, Zimbabwe, Pp. 250-254.

Hassan, R.M., (1988). Maize technology development and transfer: A GIS application for research planning in Kenya. CAB International/CIMMYT/KARI, Wallingford, U.K.

Kanampiu, F.K., Ransom, J.K., and Gressel, J., (2001). Imazapyr seed dressings for Striga control on acetolactate synthase target-site resistant maize. Crop Protection 20, 885-895.

Kanampiu, F.K., Ransom, J.K., Friesen, D., and Gressel J., 2002. Imazapyr and Pyrithiobac movement in soil and from maize seed coats to control Striga in legume intercropping. Crop Protection 21, 611-619.

Little, T.M. and Hills, F.J., (1978). Agricultural Experimentation Design and Analysis. John Wiley and Sons, 605 Third Avenue, New York, N.Y. 10016.

Odendo, M., De Groote, H., and Odongo, O.M., (2001). Assessment of Farmers' Preferences and constraints to maize Production in the moist mid-altitude zone of Western Kenya. In: ACSA (Ed.), African Crop Science Conference Proceedings. African crop science Association, Kampala, Uganda, Pp. 769-775.

Odhiambo, G.D. and Ariga E.S., (2001). Effect of Intercropping maize and beans on Striga incidence and grain yield. Seventh Eastern and Southern Africa Regional Maize Conference $11^{\text {th }}-15^{\text {th }}$ February, 2001. Pp. 183-186.

Odhiambo, G. and Woomer, P.L., (2005). Striga emergence and seed bank dynamics under different maize management practices in Western Kenya. In: Tenywa, J.S., Adipala E., Nampala, P., Tusiime, G., Okori P. and Kyamuhangire, W. (Eds.). African Crop Science Conference Proceedings, Kampala, Uganda. Vol. 7 pp. 473- 477.

Pusino, A., Petretto, S., and Gessa, C., (1997). Adsorption and desorption of imazapyr by soil. Journal of Agriculture and Food chemistry 45, 1012-1016.

Ramaiah, K.V., Parker, C., Vasudeva Rao, M.J., and Musselman, L.J., (1983). Striga identification and control handbook. Information Bulletin No. 15. Patancheru, A.P., India: International crops Research Institute for the Semi - Arid Tropics.

SAS, (2003). SAS/STAT User's Guide, Release 9.1. Cary, NC, Cary, NC.

Tittonell, P., Vanlauwe, B., Leffelaar, P.A., Giller, K.E., (2005). Estimating yields of tropical maize genotypes from non-destructive, on-farm plant morphological measurements. Agriculture, Ecosystems and Environment 105: 213-220.

Tu, (2004). Weed Control Methods Handbook, The Nature Conservancy from <http://tncweeds.ucdavis.edu> accessed on $28 / 02 / 2008$.

Vanlauwe, B., Kanampiu, F., Odhiambo, G.D., De Groote, H., Wadhams, L.J. and Khan, Z.R., (2008). Integrated management of Striga hermonthica, stemborers and declining soil fertility in Western Kenya. Field Crops Research 107:102-115. 